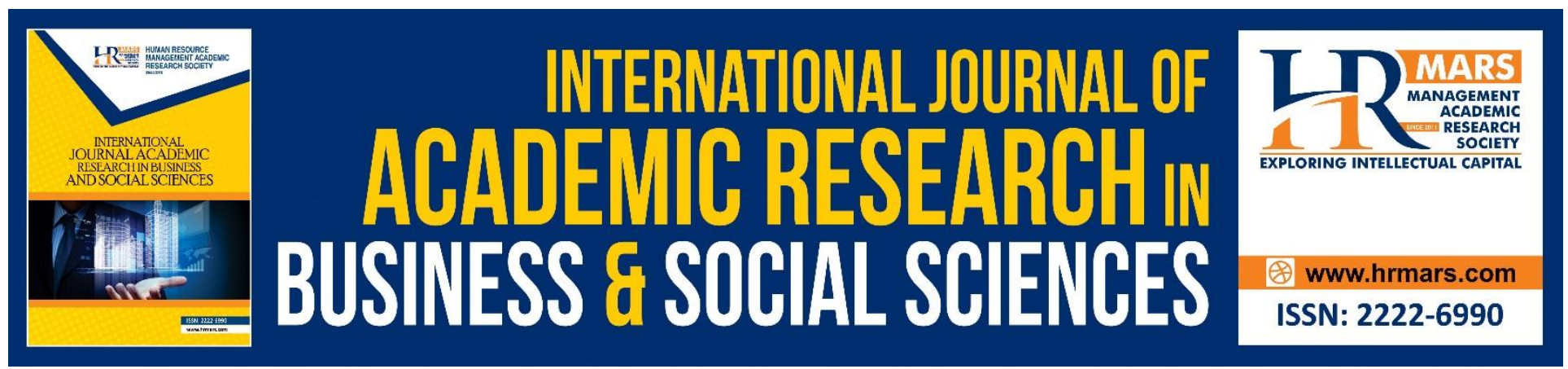

\title{
The Effects of Ethical Climate on Bullying Behavior in the Workplace
}

\author{
Uzma Naz, Syeda Sidra Tasneem, Rubina Jabeen, Reeba Saleem
}

To Link this Article: http://dx.doi.org/10.6007/IJARBSS/v9-i3/5776

DOI: $10.6007 /$ IJARBSS/v9-i3/5776

Received: 02 Feb 2019, Revised: 17 Feb 2019, Accepted: 21 March 2019

Published Online: 23 March 2019

In-Text Citation: (Naz, Tasneem, Jabeen, \& Saleem, 2019)

To Cite this Article: Naz, U., Tasneem, S. S., Jabeen, R., \& Saleem, R. (2019). The Effects of Ethical Climate on Bullying Behavior in the Workplace. International Journal Academic Research Business and Social Sciences, 9(3), 1157-1170.

Copyright: (C) 2019 The Author(s)

Published by Human Resource Management Academic Research Society (www.hrmars.com)

This article is published under the Creative Commons Attribution (CC BY 4.0) license. Anyone may reproduce, distribute, translate and create derivative works of this article (for both commercial and non-commercial purposes), subject to full attribution to the original publication and authors. The full terms of this license may be seen

at: $\underline{\text { http://creativecommons.org/licences/by/4.0/legalcode }}$

Vol. 9, No. 3, 2019, Pg. $1157-1170$

http://hrmars.com/index.php/pages/detail/IJARBSS

JOURNAL HOMEPAGE

Full Terms \& Conditions of access and use can be found at http://hrmars.com/index.php/pages/detail/publication-ethics 


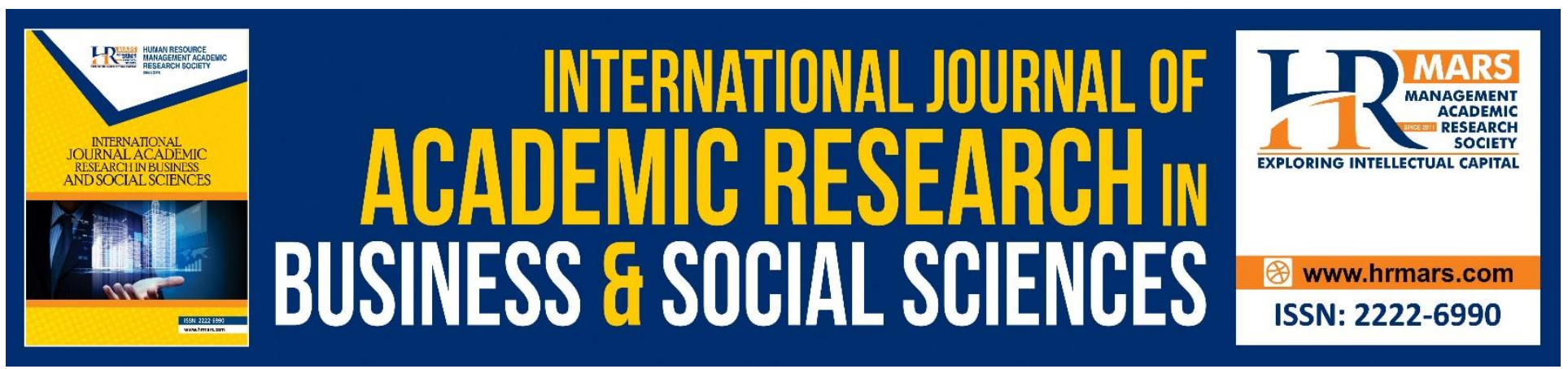

\title{
The Effects of Ethical Climate on Bullying Behavior in the Workplace
}

\author{
Uzma Naz¹, Syeda Sidra Tasneem², Rubina Jabeen ${ }^{4}$, Reeba \\ Saleem ${ }^{3}$ \\ ${ }^{1}$ Post RN, Nursing College, The Superior College Lahore \\ ${ }^{2}$ Director, Nursing College, The Superior College Lahore \\ ${ }^{3}$ Principal, Nursing College, The Superior College Lahore \\ ${ }^{4}$ Assistant Professor, Nursing College, The Superior College Lahore \\ ${ }^{1}$ Email: uzmanaz770@gmail.com
}

\begin{abstract}
Several aspects of the relationship between Ethical climate and bullying have been explored. The aim of this study is to find out the effects of Ethical climate upon the relationship between bullying behavior. This study contributes to the existing research by taking the effects of bullying behavior into account. Regression analysis was performed to examine the relationship between variables. Regression was done to measure the relationship between ethical climate and bullying behavior. The more positive is ethical climate, the less is bullying behavior. Bullying has negative impacts on work productivity of organization. The relationship of ethical climate and organizational outcomes suggested that, this climate has effects upon people' perceptions regarding their job satisfaction and psychological wellbeing. Most of the time effective reactions in the work place are positively associated to perception of comfortable environment. Positive ethical environment should be maintained to subside the deviant behavior and bullying at workplace. Ethical climate helps to get right decision for any organization struggling to decrease the level of bullying. It is demanding to improve the level of ethical decision making, which help to decrease the level of bullying in the workplace. Additionally it is more important for any organization to encourage the dimension of ethical-decision making, if their aim is to decrease bullying behavior. So ethical climate enhances positive relationship with bullying. In an organization where bullying behavior is low, ethical climate will be automatically prevalent
\end{abstract}

Keywords: Bullying Behavior, Ethical Climate 


\section{Introduction}

Ethical Climate of workplace is defined as the same opinion of "what is ethically accurate behavior" and how ethical problems should be manage and control in workplace (Peterson ,2002).Ethical climate is one of the different types of organizational climate. Organizational climate is the composition of organizational environment; worker's perception of organizational practices and procedures; and employees interaction (Bulutlar \& Öz ,2009). Among these, an ethical climate is more beneficial for both co-workers and organizational output. There is a perception by some psychological thinkers that working in ethical climate resolves most of the ethical dilemmas and helps to get right decision for organization and also improve the working environment(Simha \& Cullen, 2012). Ethical climate of an institution is actually based on the way the member of that organization perceive organizational norms and practice's that usually indicate what is considered right and wrong within an organization. So, they help workers to identify and solve ethical issues raised at workplace by providing them answers to "What should I do?" while facing moral problems. In this way, worker can assess situation and relate it with normative system which is preset by organization in the form of ethical codes (Cullen, Parboteeah et al. 2003). Typology of moral climates has three types or standards of moral judgment: egoism; benevolence; and principle. These shape the three primary ethical climates. In these ethical, climates organizational norms support self-interest, interests of particular social groups and the abstract principles respectively.

Ethical behavior can be promoted the self-reliance climate and that is mostly established on confidential mortality. Independent climate cannot be practiced in an environment where there is disobedience lying. Ethical climate enhance the employees behavior not only that this type of climate increase the organizational out comes and work productivity (Bulutlar \& oz, 2009).

Work place bullying is defined as frequent harassing actions aimed at affecting one's quality of life at work place. Psychologically, classified as one of the most extreme stress factors at work place. Bullying and mobbing basically manifests as a result of anxiety disorder in the culprits behavior (Aykans ,2016). In the last few decades/years researchers have recognized that disruptive behavior at workplace is very important subject. Aggressiveness ranges from violence to rude behavior. Among which violence is more evident and gets immediate attention but bullying is mostly underestimated despite of its harmful nature. It is revealed that bullying is a significant cause of stress(Bulutlar \& Öz, 2009).

The impact of bullying and harassment on the employer and the person are extraordinary that includes not only decreased creativity and loss of productivity but high turnover rate. People tend to call in sick when they experience bullying at the workplace and it leads to decreased efficiency. These small things in the end have a cumulative effects ,leading to a bigger negative impact, Other coworker's also suffer due to the environment The effect is also in the form of financial losses due to legal measures that taken against bullying and harassment(Vega \& Comer, 2005). Bullying and mobbing are used interchangeably but there is a little difference in both terms. Bullying is rude behavior that is directed from manager to employees and the mobbing is among peers. Despite of the differences, the both have same systematic and repetitive process in which level of aggressiveness becomes severe with the passage of time. The role of ethical climate is significant in bullying behavior. Many organizations nip it in the bud but it is often experiences in the organizations where employees are unable to differentiate between "right" and "wrong". There is a significant 
positive relationship between ethical climate and bullying behavior. As In an organization where bullying behavior is low, ethical climate will automatically be prevalent. If organizational rules are strictly followed chances of bullying become less and environment becomes safe. Bullying may affect physical as well as mental health .People work in a caring climate think about other's well-being and not engage in harmful behavioral person exposed to bullying lack of stability in his life because he is damaged physically and mentally. When the climate will be ethically caring, employees will contribute more to organizational outcomes and will not be concerned about consequences. So the primary aim of the study is to find out the relationship between ethical climate and bullying behavior. The more positive is ethical climate and the less is bullying. Bullying negatively impact's on work productivity of organization and also mental health of the employees.

(Bulutlar \& Öz ,2009). Studies have revealed that nearly $95 \%$ of employees face bullying behavior at workplace and only $10 \%$ gets attention (Samnani \& Singh ,2012).

\section{Objectives}

- Investigate the effects of ethical climate on bullying behavior.

- Find out the relationship between ethical climate and Bullying Behavior

\section{Problem Statement}

Workplace bullying is serious problem that affecting the nurses work performance and cause of anxiety disorder. Bullying also damage morale of teamwork and interferes with productivity. The impact of bullying in nursing profession decreased creativity, loss of productivity and high turnover rate at work place. Bullying behavior such as verbal abuse has a negative impact on the self-esteem of nurses as well as their morale and professional error rates. Those who have suffered violence at work place, have decrease job satisfaction, poor motivation, as well as experience disturbances in social relationships inside and outside the organization.

\section{Significance}

Based on the results of this study, the administration can understand that workplace bullying is serious problems that affecting the nurses' work performance and cause of anxiety disorder. Bullying also damage morale of teamwork and interferes with productivity. The impact of bullying in nursing profession decreased creativity. So Ethical climate is very important because it increase the quality of work in an organization, improve the employee's morale and enrich organization outcome. Where the ethical climate is better the bullying behavior will be automatically decreased. This comfortable environment always positive effect on work performance of the nurses.

\section{Literature Review}

There has been many researchers developed interest in ethical behavior in the work place and after recent scandals improve this interest. Ethical climate of work place has been defined as the same opinion of "what is ethically accurate behavior" and how ethical problems should be manage and control in workplace. Ethical climate determines decision making, moral criteria for understanding and behavior in response to ethical issues (Peterson ,2002). Ethical climates perform many functions in workplace. They help workers to solve their ethical issues by providing them answers to" What 
should I do? When they face moral problems(Cullen, Parboteeah et al. ,2003). Ethical codes are set in an organization and everyone is supposed to follow them, One who feels to such rules may face termination and expulsion (Peterson ,2002). Ethical Climate of an organization is actually based on the way the member of that organization perceive organizational norms and practices that usually indicate what is considered right and wrong within an organization (Bulutlar \& oz,2009). Bullying is the act of misbehavior in which the respective target is subjected to any gossip, abuse or illmannered, It can cause may be psychological and physical health issues to the people who are bullied (Stouten, Baillien et al. ,2010). People left an organization because of bullying, not only that, decreased creativity and loss of productivity have also been noticed. People tend to call in sick when they experience bullying at the work place and it leads to decreased efficiency. These small things in the end have a cumulative effect that leading to a bigger negative impact, other co-workers also suffer due to the environment. The effect is also in the form of financial losses due to the legal measures taken against bullying and harassment (Vega \& Comer 2005). There is a significant positive relationship between ethical climate and bullying behavior. As In an organization where bullying behavior is low, ethical climate will automatically be prevalent. If organizational rules are strictly followed chances of bullying become less and environment becomes safe. Bullying may affect physical as well as mental health (Bulutlar \& Oz, 2009).

This study shows that organizational environment climate affects commitment of employees. Ethical decision making decreases bullying behavior in employees and by promoting this behavior organizational outcome will be better (Bulutlar \& Öz, 2009).

Therefore an empirical study conducted in data collected from 190 participants and the study results showed that highly ethical environment of that organization affects positively their employees. Employees are stickier to their organizational interests and they are more adhering to their organizational rules and regulations. Their attitude is helping towards other employees of the organization and also towards organization itself. These employees in ethical environment show selfdevelopment and efficiency(Elçi \& Alpkan, 2009). A study shows that over past 20 years bullying on work place not only affected by workplace violence but also affected by personal characteristics (psychological, physiological and cultural background) that negatively affects the bullying behavior(Samnani \& Singh ,2012).

This study conducted to investigate the impacts of bullying behavior upon the ethical climate. Researcher explores the gap that certain factors are confounding these relationships. So these factors should also be considered. These factors are cultural differences and different psychological behavior (Bulutlar \& Öz, 2009).

\section{Research Methodology}

\section{Introduction}

This research is conducted to examine the effects of ethical climates on bullying behavior at workplace. 
INTERNATIONAL JOURNAL OF ACADEMIC RESEARCH IN BUSINESS AND SOCIAL SCIENCES

Vol. 9, No. 3, March, 2019, E-ISSN: 2222-6990 C 2019 HRMARS

\section{Study design}

A descriptive cross sectional research design will be used for this research to analyse "the effect of ethical climate on bullying behavior in work place".

\section{Setting}

Setting of the study will be the Jinnah hospital, Lahore.

\section{Target population}

The research design was correlational study. The population of the study was 250 Nurses from Jinnah Hospital Lahore. The participants were taken from different departments in Jinnah Hospital, Lahore.

\section{Sample Size and sampling techniques}

Data was collected through self-administered Questionnaire and simple random sampling technique used for selection of participants. Data was collected from the charge Nurses. The 110 copies of questionnaire were circulated given a free hand 105 copies were return and 5 copies missing value and eliminate 5 copies from the total, to complete it and return it.

\section{Research tool}

A self-administered and modified version of questionnaire used in the article "Ethical Climate on bullying behavior in the work place" for data collection. Questionnaire comprises of three sections: "Section A" (Demographic data including name, Age, Gender, institute, department). "Section B" comprises of 10 questions regarding information to evaluate the employees interpreted of their ethical climate and bullying behavior. Bullying was calculated by the Authorized version of the Negative Acts Questionnaire (Einarsen and Raknes, 1997; Hole et al., 2004; Mikkelsen and Einarsen, 2001) And last (section C) includes 10 questions regarding the information "how do you feel at workplace". Section B \& C are designed on "lickert scale" ranging options from "strongly disagree" to "strongly agree".

\section{Data Collection Plan}

Data collection plan is one of the main sources to collect data. The data was collected through survey and the questionnaires were floated by the researcher herself. The 110 copies of questionnaire were circulated to the nurses and recovered on the spot. 5 questionnaires were missing while 105 questionnaires were valid.

\section{Data Analysis}

Data analysis was done by SPSS version 20. Statistical computer software for data analysis. This is a descriptive study and all the descriptive statistics has obtained through the SPSS software.

\section{Including Criteria}

$\checkmark$ Nursing employees of different department.

$\checkmark$ Willing to participate

$\checkmark$ Those who understands English 


\section{Excluding Criteria}

$\checkmark$ Students Nursing BScN Generic

$\checkmark$ Students outside from university of Lahore

\section{Time Framework}

This study has taken approximately 2-3 months.

\section{Informed Consent}

Consents has taken from all the participants and free hand has given to the participants to take part in the study or refused to participate, participants have also the right to mentioned name or not.

\section{Ethical consideration}

A full written consent had taken from Participants through a consent form attached to the questionnaire. Confidentiality has been ensured. The rights of participants were protected by Nuremberg Code of Ethics.

\section{Research Framework:}

\section{Ethical climate}

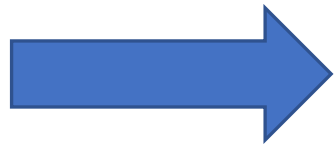

\section{Bullying Behaviour}

\section{Hypothesis}

Hypothesis 1: There is no negative relationship between ethical climate and bullying behavior. Null Hypothesis HO: There is negative relationship between ethical climate and bullying behavior.

Demographic Analysis

Table. 1 Age Group

\begin{tabular}{|ll|l|l|l|l|}
\hline & $\begin{array}{l}\text { Freque } \\
\text { ncy }\end{array}$ & Percent & $\begin{array}{l}\text { Valid } \\
\text { Percent }\end{array}$ & $\begin{array}{l}\text { Cumulative } \\
\text { Percent }\end{array}$ \\
\hline \multirow{4}{*}{ Valid } & $18-25$ & 20 & 19.0 & 19.0 & 19.0 \\
& $25-35$ & 76 & 72.4 & 72.4 & 91.4 \\
& $35-50$ & 9 & 8.6 & 8.6 & 100.0 \\
& Total & 105 & 100.0 & 100.0 & \\
\hline
\end{tabular}

Table 1 . Shows that $19.0 \%$ of participants be linked to $18-25$ age groups. $72.4 \%$ of participants be linked to $25-35$ age group.8.6\% of participants be linked to 35-50 age groups. Graph and table give us clear details. 
INTERNATIONAL JOURNAL OF ACADEMIC RESEARCH IN BUSINESS AND SOCIAL SCIENCES Vol. 9, No. 3, March, 2019, E-ISSN: 222 2-6990 @ 2019 HRMARS

Table.2 GENDER
\begin{tabular}{|l|l|l|l|l|}
\hline & Frequency & Percent & Valid percent & Cumulative percent \\
\hline Male & 5 & 4.8 & 4.8 & 4.8 \\
Valid female & 100 & 95.2 & 95.5 & 100.0 \\
Total & 105 & 100.0 & 100.0 & \\
\hline
\end{tabular}

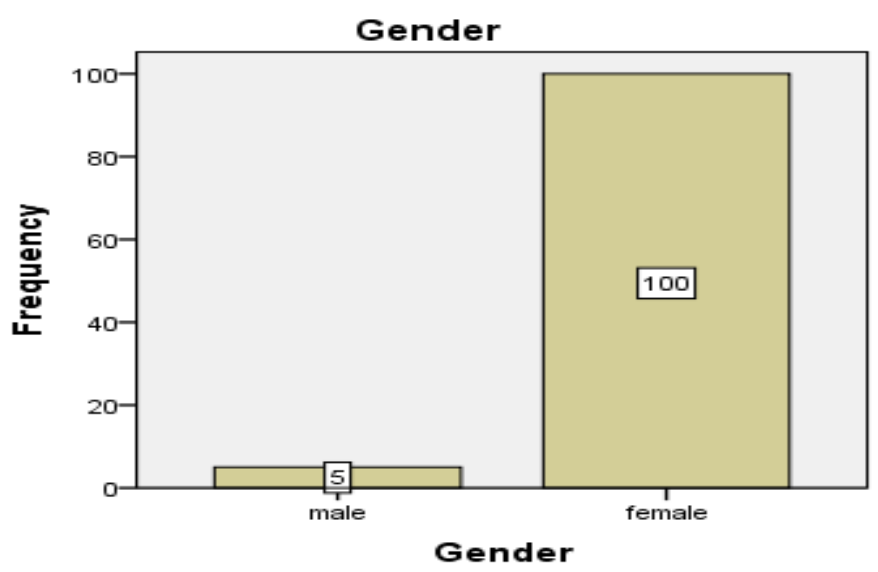

Table .2 shows that $4.8 \%$ respondents are male employee and $95.2 \%$ respondent is of female and data was collected from both male and female. So as we see distribution in the graph.

Table.3 Marital status

\begin{tabular}{|l|l|l|l|l|}
\hline & Frequency & Percent & $\begin{array}{l}\text { Valid } \\
\text { percent }\end{array}$ & $\begin{array}{l}\text { Cumulative } \\
\text { percent }\end{array}$ \\
\hline Single & 38 & 36.2 & 36.2 & 36.2 \\
Valid married & 67 & 63.8 & 63.8 & 100.0 \\
Total & 105 & 100.0 & 100.0 & \\
\hline
\end{tabular}

Table .3 and graph shows that data was collected from both unmarried and married respondents. $36.2 \%$ respondents are unmarried.63.8\% respondents are unmarried. 
Table 4 Qualification

\begin{tabular}{|c|l|l|l|l|}
\hline & $\begin{array}{l}\text { Frequenc } \\
\mathrm{y}\end{array}$ & Percent & $\begin{array}{l}\text { Valid } \\
\text { Percent }\end{array}$ & $\begin{array}{l}\text { Cumulative } \\
\text { Percent }\end{array}$ \\
\hline F.A/Fsc & 1 & 1.0 & 1.0 & 1.0 \\
Nursing & 93 & 88.6 & 88.6 & 89.5 \\
Viploma & 11 & 10.5 & 10.5 & 100.0 \\
post RN & 105 & 100.0 & 100.0 & \\
Total & & & & \\
\hline
\end{tabular}

Table 4 shows the qualification of the respondents that was recorded as $1.0 \%$ respondents are intermediate, $88.6 \%$ respondents are diploma in nursing, and $10.5 \%$ respondents are post RN. More details are given in table and graph

\section{Reliability}

Reliability has been tested and calculated through cronbach,s alpha that shows the reliability of each construct and how much it is reliable and valid. Many researchers use different conditions to get valid result.

Case Processing Summary
\begin{tabular}{|l|l|l|}
\hline & N & $\%$ \\
\hline Valid & 105 & 100.0 \\
Cases Excluded & 0 & .0 \\
Total & 105 & 100.0 \\
& & \\
\hline
\end{tabular}

Reliability statistics

\begin{tabular}{|l|l|l|}
\hline $\begin{array}{l}\text { Cronbach,s } \\
\text { Alpha }\end{array}$ & $\begin{array}{l}\text { Cronbach,s } \\
\text { Alpha based } \\
\text { On Standardized } \\
\text { Items }\end{array}$ & $\begin{array}{l}\text { N of } \\
\text { Items }\end{array}$ \\
\hline .909 & .914 & 43 \\
\hline
\end{tabular}

The value of Cronbach,s alpha for effects of ethical climate is greater than $0.70 \%$ thus this result shows the standard requirement of reliability and this study variables are reliable. 


\section{Validity}

KMO Bartlett's assumptions

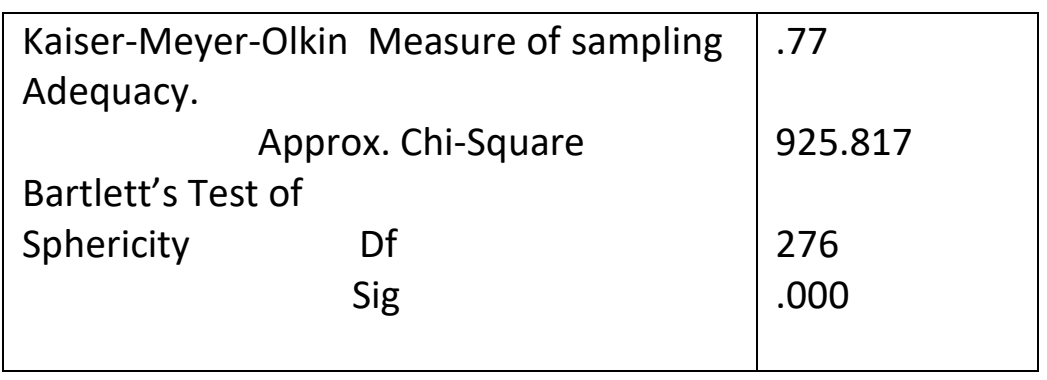

\section{Total Variance Explained}

\begin{tabular}{|l|l|l|l|}
\hline \multirow{2}{*}{\begin{tabular}{l} 
Componen \\
\cline { 2 - 4 }
\end{tabular}} & \multicolumn{3}{|l|}{ Extraction Sums of Squared Loadings } \\
\cline { 2 - 4 } & Total & $\begin{array}{l}\% \\
\text { Variance }\end{array}$ & $\begin{array}{l}\text { Cumulative } \\
\%\end{array}$ \\
\hline 1 & 6.093 & 25.386 & 25.386 \\
2 & 2.897 & 12.072 & 37.457 \\
3 & 1.600 & 6.668 & 44.126 \\
4 & 1.444 & 6.018 & 50.144 \\
5 & 1.330 & 5.540 & 55.684 \\
6 & 1.179 & 4.912 & 60.595 \\
\hline
\end{tabular}

Extraction Method: Principal Component Analysis.

1 independent variable (Ethical climate) and 1 dependent variable (Bullying behavior). Table shows that KMO value is above .50 and Bartlett test is significant ( $p, 0.05)$. The whole set criteria fulfilled and instruments of this study are valid.

\section{Correlations}

Descriptive Statistics

\begin{tabular}{|l|l|l|l|}
\hline & Mean & $\begin{array}{l}\text { Std. } \\
\text { Deviation }\end{array}$ & $\mathbf{N}$ \\
\hline Ethical Climate & 3.32 & .459 & 105 \\
$\begin{array}{l}\text { Bullying } \\
\text { Behavior }\end{array}$ & 3.03 & .573 & 105 \\
\hline
\end{tabular}


INTERNATIONAL JOURNAL OF ACADEMIC RESEARCH IN BUSINESS AND SOCIAL SCIENCES

Vol. 9, No. 3, March, 2019, E-ISSN: 222 2-6990 @ 2019 HRMARS

\section{Correlation}

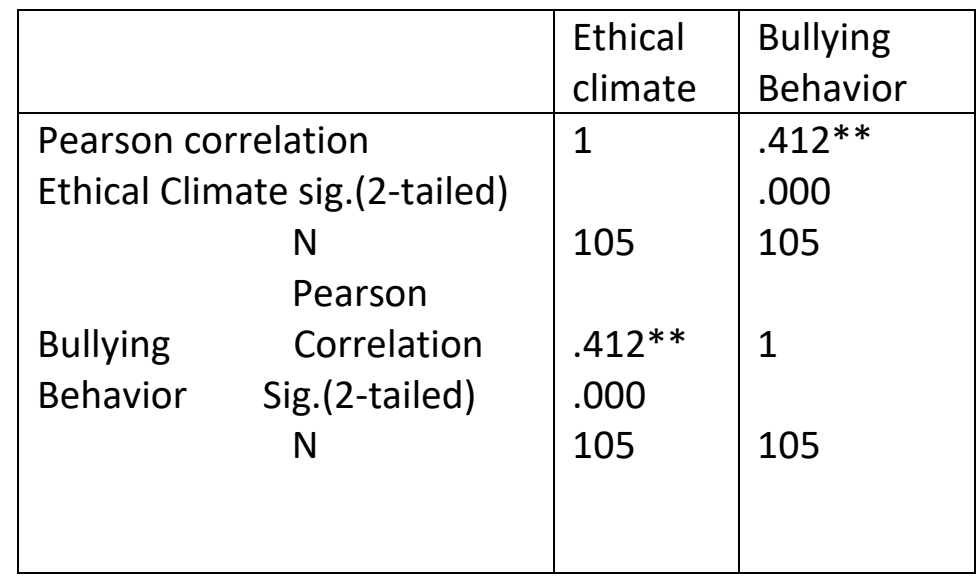

**Correlation is significant at the 0.01 level (-tailed).

This table shows correlation between variables. Result portrayed that ethical climate positively correlation with bullying behavior $(R=0.412)$ and $(p=0.0)$. Similar ethical climate significantly correlated with bullying behavior. These result provided initial support to hypothesis formulated in the current study.

Regression

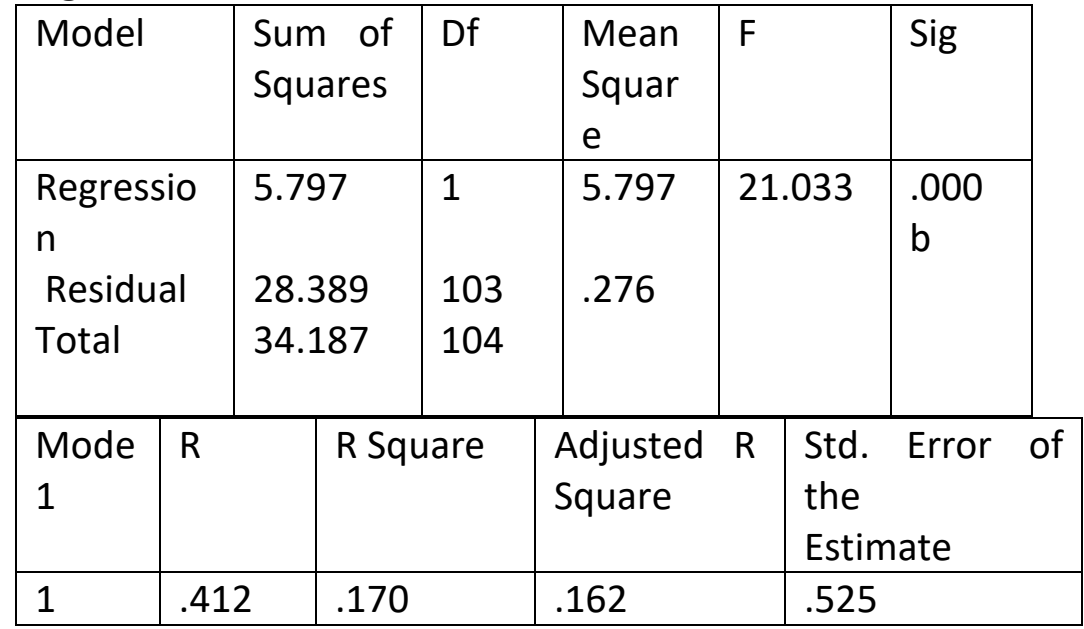

Regression analysis shows the relationship between variables. That shows the direct effects of ethical climate on bullying behavior, so multiple regression shows hypothesis relationship.

Table 1.Model Summary

a. Predictors: (Constant), Ethical Climate

Table 1 show the model summary of the current result which is total $.170 \%$ variation occur bullying behavior.

Table 2.ANOVAa 
INTERNATIONAL JOURNAL OF ACADEMIC RESEARCH IN BUSINESS AND SOCIAL SCIENCES Vol. 9, No. 3, March, 2019, E-ISSN: 2222-6990 @ 2019 HRMARS

a. Dependent Variable: Bullying Behavior

b. Predictors: (Constant), Ethical Climate

Anova is significant $(p<0.5)$ and it represent that the research model is fit/significant.

Table 3.Coefficients

\begin{tabular}{|c|c|c|c|c|c|c|}
\hline \multirow{2}{*}{\multicolumn{2}{|c|}{ Model }} & \multicolumn{2}{|c|}{$\begin{array}{l}\text { Unstandardized } \\
\text { coefficients }\end{array}$} & $\begin{array}{l}\text { Standardized } \\
\text { Coefficients }\end{array}$ & \multirow[t]{2}{*}{$T$} & \multirow[t]{2}{*}{ Sig. } \\
\hline & & B & Std. Error & Beta & & \\
\hline \multirow[b]{2}{*}{1} & (Constant) & 1.324 & .376 & & 3.523 & .001 \\
\hline & $\begin{array}{l}\text { Ethical } \\
\text { Climate }\end{array}$ & -.514 & .112 & .412 & -4.586 & .000 \\
\hline
\end{tabular}

a. Dependent Variable: Bullying Behavior

Table shows that impact of ethical climate have positive $(p<0.05, t=6.006)$ relationship with ethical climate. However table 3 shows that if one- unit increases ethical climate then the bullying behavior will increase with the beta value of- .514.

\section{Results}

The demographic analysis of the nurse's data mostly the participants nurses were females range of age was between 25 to35 years. Age of the nurses was $18-25$ years of staff nurses which were 20(19\%) and the $25-35$ years $76(72.4 \%)$. Nurses $67(63.8 \%)$ participant were married and the other respondents $38(36.2 \%)$ were unmarried.

The demographic analysis of the patients data were taken female nurses 100(95.2\%) and male nurses were 5 (4.8\%) Most of the respondents are of Nursing diploma 93(88.6\%) and post RN in11 (10.5\%). Reliability has been tested and calculated through cronbach, $s$ alpha. The value of cronbach, $s$ alpha the effects of ethical climate is greater than $0.70 \%$ and this result shows the standard requirement of reliability and this study of variables are reliable.

In the validity instrument was consisting of 1 independent variable (Ethical climate) and 1 dependent variable (Bullying behavior). Table shows that $\mathrm{KMO}$ value is above .50 and Bartlett test must be significant $(p, 0.05)$. The whole set criteria fulfilled and instruments of this study are valid.

In the table form Correlation analysis are displayed. It shows the relationship between two variables. The result revealed that ethical climate was positively correlated with bullying behavior $(.450$ $\mathrm{p}<.01)$.Similarly ethical climate is significantly correlated with bullying behavior.

Regression analysis was performed to examine the relationship between variable. The effects of ethical climate on bullying behavior. Regression was done to measure the relationship between ethical climate and bullying behavior. The value of $\mathrm{R}$ square was used to explain the amount of variance same thing is explained by adjusted $\mathrm{R}$ square but in a more accurate way. 
INTERNATIONAL JOURNAL OF ACADEMIC RESEARCH IN BUSINESS AND SOCIAL SCIENCES

Vol. 9, No. 3, March, 2019, E-ISSN: 222 2-6990 @ 2019 HRMARS

The result of linear regression is displayed in table. Result revealed the ethical climate the ethical climate significantly related to bullying behavior with beta value .450 $(p=.000)$ show the significant positive relationship between ethical climate and bullying behavior.

\section{Discussion}

Ethical climate is a powerful tool for superior performance. Ethical climate increase work satisfaction in organization, promotes conscience of team interest and social responsibility among the nurses (Elçi, 2009). The basic purposes of this study is to find out the relationship between ethical climates and bullying behavior. The more positive is ethical climate the less is bullying behavior. Bullying is always negatively impacts on work performance in the organization.

The relationship of ethical climate and organizational outcomes imply these climate effects people perceptions regarding their job satisfaction, psychological wellbeing. Most of the time effective reactions in the work place are positively associated to perception of comfortable environment (Martin \& Kelly, 2006). In accordance with previous studies ethical climate has stronger impact on job satisfaction in the workplace. Findings of this study suggests that climate of organization has significant impact on work place behavior. Similar to that Study supports the view that ethical behavior plays an important role in bullying. Ethical climate decrease the bullying behavior. By establishing a more favorable ethical environment employees are prevented from being targeted of bullying(Bulutlar \& Öz,2009).

A study proposed that employees need to feel that they are supported by ethical environment and they are prevented from bullying and whenever they are facing any dilemma, how to deal with them. Moreover positive ethical environment should be maintained to subside the deviant behavior and bullying at workplace (Appelbaum, 2005). In establishing ethical infrastructure in an organization, we have to cope with corporate wrongdoing, as it is important to handle problems in an organization as employees will know to react and handle bullying situations. Awareness should be raised by campaign against bullying. Along formal ethical system, informal ethical system is also important, as it tells you to behave in unethical and bullying environment.

\section{Conclusion}

Ethical climate helps to get right decision for any organization struggling to decrease the level of bullying; it is demanding to improve the level of ethical decision making. Which help to decrease the level of bullying in the workplace. Furthermore it is very powerful tool for any administration to influence the size of ethical-decision making, if their purpose is to reduce the bullying behavior. So ethical climate enhance positive relationship with bullying. In an organization where bullying behavior is low, ethical climate will be automatically prevalent.

\section{Limitations}

This study done in LHR, There are so many limitations one of them is shortage of time due to shortage of time data was collected by self from Jinnah Hospital LHR. So the kind of this research enables the calculate by using the instrument or standard units or interpreted not only authentic response. The other hand this study is conduct only nursing employees and responses have been contemplate, 
INTERNATIONAL JOURNAL OF ACADEMIC RESEARCH IN BUSINESS AND SOCIAL SCIENCES

Vol. 9, No. 3, March, 2019, E-ISSN: 222 2-6990 ¿ 2019 HRMARS

therefore ,Self-directed method is applied for the data collection and there are many methods applied for the evaluate of multiple rates in the future research

\section{References}

Aykans, E. (2016). "Organizational Psychology (Employees' Psychology and Problems in the Workplace)." Acta Psychopathologica 2(1).

Bulutlar, F. and E. Ü. Öz (2009). "The effects of ethical climates on bullying behavior in the workplace." Journal of Business ethics 86(3): 273-295.

Elçi, M. and Alpkan, L. (2009). "The impact of perceived organizational ethical climate on work satisfaction." Journal of Business ethics 84(3): 297-311.

Peterson, D. K. (2002). "The relationship between unethical behavior and the dimensions of the ethical climate questionnaire." Journal of Business ethics 41(4): 313-326.

Samnani, A.-K. and Singh, P. (2012). "20 years of workplace bullying research: a review of the antecedents and consequences of bullying in the workplace." Aggression and violent behavior 17(6): 581-589.

Simha, A. and Cullen, J. B. (2012). "Ethical climates and their effects on organizational outcomes: Implications from the past and prophecies for the future." The Academy of Management Perspectives 26(4): 20-34.

Vega, G. and D. R. Comer (2005). "Sticks and stones may break your bones, but words can break your spirit: Bullying in the workplace." Journal of Business ethics 58(1-3): 101-109. 